\title{
Red Cell Distribution Width Value Supports the Diagnosis of Neonatal Sepsis in 34-42 Week Gestational Age Neonates
}

\author{
Bella Stevanny ${ }^{1}$, Atika Akbari² and Mariana ${ }^{3}$ \\ ${ }^{1}$ Department of Medicine, Sriwijaya University, Indonesia \\ ${ }^{2}$ Department of Child Health, Dr. Mohammad Hoesin General Center Hospital, Indonesia \\ ${ }^{3}$ Department of Public Health, Sriwijaya University, Indonesia
}

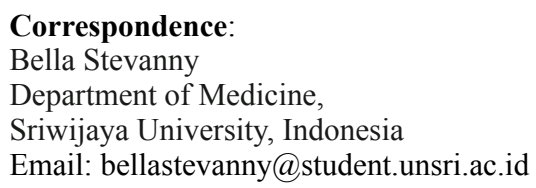

DOI: $10.3126 /$ jnps.v41i2.33189

Submitted on: $2020-07-18$

Accepted on: 2021-02-20

Acknowledgements: Dr. Verdiansah Sp.PK., MARS. and Dr. Edy Novery, Sp.A., M. Kes.

Funding: None

Conflict of Interest: None declared

Permission from IRB: Yes
To cite this article: Stevanny B, Akbari A, MarianaRed Cell Distribution Width Value Supports the Diagnosis of Neonatal Sepsis in 34-42 Week Gestational Age Neonates. J Nepal Paediatr Soc. 2021;41(2):233-8.

\section{ABSTRACT}

Introduction: Neonatal sepsis is an emergency because delayed treatment can be fatal, whereas the diagnosis is challenging because of the unspecific clinical manifestation. Bacterial culture is the gold standard for the diagnosis, but it takes several days to get the results, which often come out as negative. This study aims to determine the diagnostic value of RDW to support the diagnosis of neonatal sepsis in $34-42$ week gestational age neonates.

Methods: This cross-sectional diagnostic study used secondary data obtained from Medical Record Installation and Clinical Pathology Laboratory of Dr. Mohammad Hoesin General Central Hospital in Palembang, Indonesia. One hundred and thirty-four medical records were statistically analysed using Med Calc Version 19 to determine the cut-off point and diagnostic value of RDW in the diagnosis of neonatal sepsis.

Results: One hundred and thirty-four subjects consisting 32 septic neonates $(23.9 \%)$ and 102 non-septic neonates $(76.1 \%)$ were reviewed. Most of them were males (80/134) and preterm (73/134) with normal birth weight (99/134). At the cut-off point of $>$ $16.2 \%$, RDW value was significantly able to predict neonatal sepsis $(\mathrm{p}=0.000, \mathrm{p}<\alpha)$ with prediction power (AUC) of 0.780 (fair). The diagnostic values were sensitivity $84.37 \%$, specificity $57.84 \%$, positive predictive value $38.57 \%$, negative predictive value $92.19 \%$, positive likelihood ratio 2.00 and negative likelihood ratio 0.27 .

Conclusions: Red cell distribution width value might potentially be used as a diagnostic marker to support the diagnosis of neonatal sepsis in $34-42$ week gestational age neonates. However, further study is needed to support this statement.

Keywords: Diagnosis; Neonatal Sepsis; Neonates; Red Cell Distribution Width; RDW

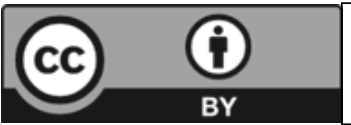

This work is licensed under creative common attribution 3.0 license 


\section{INTRODUCTION}

Neonatal sepsis is one of the main causes of neonatal morbidity and mortality. ${ }^{1}$ Study shows that around 2,202 neonates every 100,000 live births is septic, with a mortality rate of $11-19 \% .^{2}$ In Indonesia, neonatal sepsis $(13 \%)$ is the fourth leading cause of death among children under five. ${ }^{3}$ Neonatal infection is also one of the four major causes of neonatal death in Palembang, Indonesia. ${ }^{4}$ Previous study conducted in Dr. Mohammad Hoesin General Centre Hospital, Palembang, found that among 577 neonates, 94 (16.3\%) were septic neonates from June to October 2016. Only 26 $(27 \%)$ of them have a positive culture result. ${ }^{5}$

Neonatal sepsis is an uncontrolled systemic response to infection that occurred in the first 28 days of life. The diagnosis is made when Systemic Inflammation Response Syndrome (SIRS) is accompanied by suspected or proven infection. 6,7 Neonatal sepsis is still an emergency because delayed treatment can be fatal, whereas the diagnosis is challenging because of the unspecific clinical manifestation. ${ }^{8}$ Bacterial culture is the gold standard for the diagnosis of neonatal sepsis, but it takes several days to get the result. The results also often come out as negative, even when the clinical manifestation is severe, because of inadequate blood volume, minimum colony growth, or antecedent antibiotic administration. ${ }^{9}$ CRP can also support the diagnosis of neonatal sepsis, but the concentration is normal or even low in the first 12 hours of inflammation, so that serial CRP test is needed. ${ }^{10,11}$

Red cell distribution width (RDW) is red cell size variability, which is routinely evaluated as part of a complete blood count test. The value is increased in the inflammation process because of ineffective production and / or increased destruction of red cells. ${ }^{12}$ RDW value offers rapid and more costeffective neonatal sepsis diagnosis. This study aims to determine the diagnostic value of RDW to support the diagnosis of neonatal sepsis.

\section{METHODS}

This cross-sectional diagnostic study used secondary data obtained from Medical Record Installation and Clinical Pathology Laboratory of Dr. Mohammad Hoesin General Centre Hospital in Palembang, Indonesia, from June 2017 to June
2019 to determine the cut-off point and diagnostic value of RDW in the diagnosis of neonatal sepsis. Medical records of $34-42$ week gestational age neonates suspected of having an infection with complete blood count data were included.

The exclusion criteria were neonates with respiratory distress (transient tachypnea of the newborn, respiratory distress syndrome, meconium aspiration syndrome) or Apgar score at five minutes after birth less than five, congenital heart disease, history of blood transfusion before the complete blood count, and mother who were diagnosed with AIDS (Acquired Immunodeficiency Syndrome). The diagnosis of sepsis in the medical record was made according to the Clinical Practice Guideline of Child Health Department under the supervision of a neonatologist, which was clinical sepsis supported by one or more laboratory examination: (1) leukocyte count $<5,000 / \mathrm{mm}^{3}$ or $>34,000 /$ $\left.\mathrm{mm}^{3}\right)$, (2) Immature / Total neutrophil ratio $\geq 0.2$, (3) micro-ESR (Estimated Sedimentation Rate) $>15$ $\mathrm{mm} /$ hour, (4) CRP $>9 \mathrm{mg} / \mathrm{dL}$, or (5) positive blood culture. ${ }^{13}$ This study was approved by the Mohammad Hoesin Central General Hospital and Faculty of Medicine Sriwijaya University Health Research Review Committee.

Characteristic data (gender, gestational age, birth weight), laboratory data (RDW value), and diagnosis were obtained from medical records. One hundred and thirty-four medical records of suspected infection neonates that fulfil the inclusion criteria were statistically analysed using MedCalc Version 19 to determine cut-off value using receiver operation characteristic (ROC) curve and diagnostic value of RDW in the diagnosis of neonatal sepsis using cross-tabulation.Subjects were then divided in two groups consisting of neonates with RDW value lower than the cut-off value and neonates with RDW value higher than the cut-off value. Comparison of the diagnosis of neonatal sepsis between RDW groups was analysed using Chi-square with a significance level of $p<$ 0.05 .

\section{RESULTS}

One hundred and thirty-four subjects consisting of 32 septic neonates (23.9\%) and 102 non-septic neonates $(76,1 \%)$ were reviewed. Characteristic data (gender, gestational age, birth weight) and 
Table 1. Characteristic data of subjects

\begin{tabular}{|c|c|c|c|c|c|c|}
\hline \multirow[t]{2}{*}{ Characteristics } & \multirow[t]{2}{*}{$\mathbf{n}$} & \multirow[t]{2}{*}{$\%$} & \multicolumn{2}{|c|}{ Sepsis } & \multicolumn{2}{|c|}{ Non-sepsis } \\
\hline & & & $\mathbf{n}$ & $\%$ & $\mathbf{n}$ & $\%$ \\
\hline \multicolumn{7}{|l|}{ Gender } \\
\hline Male & 80 & 59.7 & 22 & 68.7 & 58 & 56.9 \\
\hline Female & 54 & 40.3 & 10 & 31.3 & 44 & 43.1 \\
\hline \multicolumn{7}{|l|}{ Birth weight } \\
\hline Low $(1,500-2,500 \mathrm{~g})$ & 35 & 26.1 & 3 & 9.4 & 32 & 31.4 \\
\hline Normal $(>2,500 \mathrm{~g})$ & 99 & 73.9 & 29 & 90.6 & 70 & 68.6 \\
\hline \multicolumn{7}{|l|}{ Gestational age } \\
\hline Pre-term & 73 & 54.5 & 17 & 53.1 & 56 & 54.9 \\
\hline Term & 61 & 45.5 & 15 & 46.9 & 46 & 45.1 \\
\hline \multicolumn{7}{|l|}{ RDW value } \\
\hline$>16.2 \%$ & 70 & 52.2 & 27 & 84.4 & 43 & 42.2 \\
\hline$\leq 16.2 \%$ & 64 & 47.8 & 5 & 15.6 & 59 & 57.8 \\
\hline Total & 134 & 100 & 32 & 100 & 102 & 100 \\
\hline
\end{tabular}

RDW value is shown in Table 1. Most of the subjects are preterm males with normal birth weight. Table 2 shows the cross-tabulation of RDW values and neonatal sepsis.

At the cut-off point of $>16.2 \%$, RDW value is significantly able to predict neonatal sepsis ( $p=$ $0.000, \mathrm{p}<\alpha$ ) with prediction power (AUC) of 0.780 (fair) with $95 \%$ CI $0.690-0.869$ shown in Figure 1. The diagnostic values are sensitivity $84.37 \%$ (95\% CI $67.21 \%$ - 94.72\%), specificity $57.84 \%$ (95\% CI $47.66 \%$ - 67.56\%), positive predictive value $38.57 \%$ (95\% CI $27.17 \%$ $50.97 \%)$, negative predictive value $92.19 \%$ (95\% CI $82.70 \%-97.41 \%$ ), positive likelihood ratio 2.00 (95\% CI $1.53-2.63)$, and negative likelihood ratio 0.27 (95\% CI $0.12-0.61)$.

The ROC curve shows that the optimum sensitivity and specificity of RDW value to support the

Table 2. Cross-tabulation of RDW values and neonatal sepsis

\begin{tabular}{|lrrr|} 
RDW & \multicolumn{2}{c}{ Neonatal sepsis } & \multicolumn{2}{c}{ Total } \\
\cline { 2 - 4 } Value & \multicolumn{1}{c}{ Sepsis } & Non-sepsis & \\
\hline$>16.2 \%$ & 27 & 43 & 70 \\
$\leq 16.2 \%$ & 5 & 59 & 64 \\
Total & 32 & 102 & 134 \\
\hline
\end{tabular}

diagnosis of neonatal sepsis is $84.37 \%$ and $57.84 \%$ with prediction power (AUC) of 0.780 (fair).

\section{DISCUSSION}

Neonatal sepsis remains a major problem because delayed treatment can be fatal, whereas the diagnosis is challenging because of the unspecific clinical manifestation. ${ }^{8}$ Of the 134 subjects, 80 $(59.7 \%)$ were males. This may be explained by the fact that the microRNA gene is located in the $\mathrm{X}$ chromosome. The gene regulates globulin protein synthesis that is needed for immunity. Females have two $\mathrm{X}$ chromosomes $(\mathrm{XX})$, whereas males only have one X chromosome (XY). Therefore,

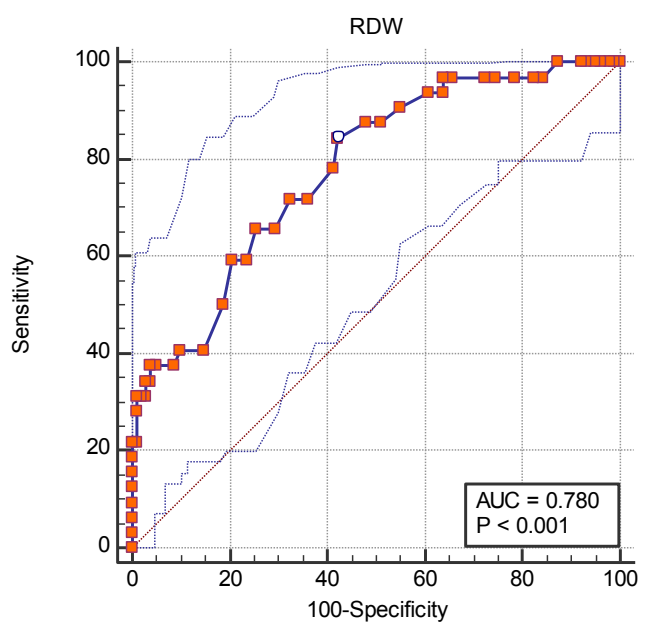

Figure 1. ROC curve of sensitivity and specificity of RDW value 
males are less immunologically-protected than females. ${ }^{14,15}$

Most subjects with a suspected infection had a gestational age of $<37$ weeks $(53.1 \%)$. This finding is consistent with the theory that preterm neonates have immature immunity so that the phagocytosis as body defence against infection is impaired. Preterm neonates also receive less passive antibody that is transferred transplacentally since 20 weeks gestational age. Moreover, prolonged hospitalisation of preterm neonates increases the risk of nosocomial infection. ${ }^{7,16}$ Neonates with low birth weight also need prolonged hospitalisation and have underdeveloped immunity making them more vulnerable to infection. On the other hand, most of the subjects of this study were neonates with normal birth weight $(73,9 \%)$. This might be because we excluded neonates with gestational age less than 34 week gestational age, which usually have lower birth weight. ${ }^{17,18}$

The mechanism responsible for the increase of RDW in neonatal sepsis is not yet clearly described. Inflammatory cytokines can modulate erythropoiesis with two pathways (1) suppression of erythroid cell maturation in bone marrow or (2) inhibition of Epo gene transcription in the kidney or liver. Inflammatory cytokines cause Epo desensitization, which then obstructs erythroid progenitor cell proliferation and proerythroblast maturation resulting in bone marrow erythropoiesis suppression. ${ }^{19}$ Normal erythropoiesis occurs as a response of erythropoietin (Epo) increase in plasma, which is stimulated by oxygen perfusion decrease with the purpose to restore blood oxygen capacity. ${ }^{20}$ Epo production can be suppressed by TNF- $\alpha$, IL-1 $\beta$, and IL- $6 .{ }^{21,22}$ Therefore, the ability to restore blood oxygen capacity is compromised. However, the erythropoiesis process is not entirely obstructed. Severe hypoxic conditions can stimulate Epo stronger and increase erythroid activity. In the end, these mechanisms cause immature erythrocyte production so that the RDW value is increased. ${ }^{20}$

At the cut-off point of $>16.2 \%$, RDW value was significantly able to predict neonatal sepsis $(\mathrm{p}=$ $0.000, p<\alpha$ ) with area under the curve (AUC) of 0.780 (fair). The diagnostic values were sensitivity
$84.37 \%$, specificity $57.84 \%$, positive predictive value $38.57 \%$, negative predictive value $92.19 \%$, positive likelihood ratio 2.00 , and negative likelihood ratio 0.27. An Egypt prospective casecontrol study with 162 subjects reported that RDW value was significantly able to predict neonatal sepsis $(p<0.001)$ with prediction power (AUC) of 0.739 (fair) at the cut-off point of $>18 \%$ (sensitivity $64.3 \%$, specificity $8.6 \%$ ) and AUC of 0.924 (excellent) at the cut-off point of $>14.3 \%$ (sensitivity $85 \%$, specificity $100 \%$ ). ${ }^{6}$ A previous cross-sectional study with 50 subjects suspected for neonatal sepsis in Malang found that RDW value at the cut-off point of $16.5 \%$ had $53 \%$ sensitivity and $58 \%$ specificity. ${ }^{23}$

In this study, the exclusion criteria were strict by excluding neonates with less than 34 week gestational age and respiratory distress. Therefore, intervening factors affecting RDW values were minimalised. However, this study has limitations. This study used secondary data so that it was difficult to obtain numerous data that comply with the inclusion and exclusion criteria. Therefore, the sample size was relatively small. The data was also often difficult to read and / or incomplete. Prospective studies with a large number of neonates are needed in order to generalise these findings. A parallel test with other diagnostic markers (e.g. CRP, leukocyte count) may increase sensitivity and specificity.

\section{CONCLUSIONS}

In conclusion, RDW value was sufficiently accurate to support the diagnosis of neonatal sepsis in $34-42$ week gestational age neonates with suspected infection. As such, the RDW value of more than $16.2 \%$ might potentially be used as a diagnostic marker to support the diagnosis of neonatal sepsis. It is also quicker and more costeffective than blood cultures and serial CRP so that it might help to reduce the mortality and morbidity due to neonatal sepsis. 


\section{REFERENCES}

1. Camacho-Gonzalez A, Spearman PW, Stoll BJ. Neonatal Infectious Diseases. Evaluation of Neonatal Sepsis. Pediatr Clin North Am. 2013;60(2):367-389. DOI:10.1016/j.pcl.2012.12.003

2. Fleischmann-Struzek C, Goldfarb DM, Schlattmann P, Schlapbach LJ, Reinhart K, Kissoon N. The Global Burden of Paediatric and Neonatal Sepsis: a Systematic Review. Lancet Respir Med. 2018;6(3):223-30. DOI:10.1016/ S2213-2600(18)30063-8

3. World Health Organisation. WHO-MCEE Estimates for Child Causes of Death, 2000-2015. DOI:10.1016/ S0140-6736(05)71877-8

4. Dinas Kesehatan Kota Palembang. Profil Kesehatan Kota Palembang Tahun 2014. Dinas Kesehatan Kota Palembang; 2015. DOI:0178-0000-15-104-H01-P

5. Ramadanti A, Hiasinta R, Bermawi H, Bahar E. Procalcitonin versus Combination of Micro Erythrocyte Sedimentation Rate and C-Reactive Protein for Diagnosing Neonatal Bacterial Sepsis. Paediatr Indones. 2017;57(4):205-10. DOI:10.14238/pi57.4.2017.205-10

6. Abdullah ST, Moustafa AN, Anwar AM. Prognostic Validity of Red Cell Distribution Width in Neonatal Sepsis. Int J Pediatr. 2018;6(11):8579-86. DOI:10.22038/ijp.2018.33010.2917

7. Kliegman RM. Nelson Textbook of Pediatrics, Twentieth Edition.; 2016.

8. Laishram RS, Khuraijam RD. Hematological and Biological Markers of Neonatal Sepsis. Iran J Pathol. 2013;8(3): $137-46$.

9. Hassan H, Gohil J, Desai R, Mehta R, Chaudhary V. Correlation of Blood Culture Results with the Sepsis Score and Sepsis Screen in the Diagnosis of Early-Onset Neonatal Septicemia. J Clin Neonatol. 2016;5(3):193-8. DOI: $10.4103 / 2249-4847.191263$

10. Ho KM, Lipman J. An Update on C-Reactive Protein for Intensivists. Anaesth Intensive Care. 2009;37(2):234-241. DOI:10.1177/0310057x0903700217

11. Aguiar FJB, Ferreira-Júnior M, Sales MM. C-Reactive Protein: Clinical Applications and Proposals for a Rational Use. Rev da Assoc Médica Bras. 2013;59(1):85-92. DOI:10.1016/s2255-4823(13)70434-x

12. Li N, Zhou H, Tang Q. Red Blood Cell Distribution Width: A Novel Predictive Indicator for Cardiovascular and Cerebrovascular Diseases. Dis Markers. 2017:1-23. DOI:10.1155/2017/7089493

13. Departemen Kesehatan Anak RSUP Dr. Mohammad Hoesin Palembang. Panduan Praktik Klinis Ilmu Kesehatan Anak. Departemen Kesehatan Anak RSUP Dr. Mohammad Hoesin Palembang; 2016.

14. Khair KB, Rahman MA, Sultana T. Role of Hematologic Scoring System in Early Diagnosis of Neonatal Septicemia. Bangabandhu Sheikh Mujib Med Univ J. 2011;3(2):62-7. DOI:10.3329/bsmmuj.v3i2.7053

15. Iskandar TR, Dalimoenthe NZ, Yuniaty T, Turbawaty DK. Validitas Skoring Hematologi Rodwell Untuk Deteksi Dini Sepsis Neonatorum Awitan Dini. Sari Pediatr. 2016;16(5):330-6. DOI:10.14238/sp16.5.2015.330-6

16. Wynn JL, Levy O. Role of Innate Host Defenses in Susceptibility to Early-Onset Neonatal Sepsis. Clin Perinatol. 2010;37(2):307-37. DOI:10.1016/j.clp.2010.04.001

17. Astria Y, Suwita CS, Suwita BM, Widjaya FF, Rohsiswatmo R. Low Birth Weight Profiles at H. Boejasin Hospital, South Borneo, Indonesia in 2010-2012. Paediatr Indones. 2016;56(3):155-161. DOI:10.14238/pi56.3.2016.155-61

18. Mussi-Pinhata MM, Do Nascimento SD. Neonatal Nosocomial Infections. J Pediatr (Rio J). 2001;77(1):81-96. DOI:10.2223/JPED.222

19. Macdougall IC, Cooper A. The Inflammatory Response and Epoetin Sensitivity. Nephrol Dial Transplant. 2002;17(1):48-52. DOI:10.1093/ndt/17.suppl_1.48

20. Pierce CN, Larson DF. Inflammatory Cytokine Inhibition of Erythropoiesis in Patients Implanted with a Mechanical Circulatory Assist Device. Perfusion. 2005;20(2):83-90. DOI:10.1191/0267659105pf793oa

21. Faquin WC, Schneider TJ, Goldberg MA. Effect of Inflammatory Cytokines on Hypoxia-Induced Erythropoietin Production. Blood. 1992;79(8):1987-95. DOI:10.1182/blood.v79.8.1987.bloodjournal7981987

22. Jelkmann W, Fandrey J, Frede S, Pagel H. Inhibition of Erythropoietin Production by Cytokines: Implications for the Anemia Involved in Inflammatory States. Ann N Y Acad Sci. 1994;718(1):300-9. DOI:10.1111/j. 1749-6632.1994.tb55728.x 
23. Gupita AS. Uji Hemoglobin dan Indeks Eritrosit Dalam Diagnostik dan Prognostik Pada Sepsis Neonatorum. Published online 2017. 